\title{
Prevalence and leukotoxic profile of biofilm forming Staphylococcal strains isolated from a tertiary care hospital in Mysore
}

\author{
Pradeep Halebeedu Prakash ${ }^{1}$, Gopal $\mathrm{S}^{2}$ \\ ${ }^{1}$ Pradeep Halebeedu Prakash, Department of Studies in Microbiology, University of Mysore, Manasagangotri, Mysore, \\ Karnataka, India, ${ }^{2}$ Dr. Shubha Gopal, Associate Professor, Department of Studies in Microbiology, Manasagangotri, \\ University of Mysore, Mysore, India.
}

Address for Correspondence: Dr. Shubha Gopal, Associate Professor, Department of Studies in Microbiology, Manasagangotri, University of Mysore, Mysore. Email: shubhagopal_mysore@yahoo.com

\begin{abstract}
Background: Staphylococci causes chronic skin infections, device associated infections, ear infections, bone infections and post-operative infections. It secretes toxins such as Pantone-Valentine Leukocidin which prolongs the infection in hospitalized patients. Aim: To investigate the prevalence of Staphylococcal biofilm associated strains and to understand the correlation between biofilm production, multi-drug resistance and leukotoxicity. Methods: 280 Staphylococcal clinical isolates obtained from biofilm associated infections are collected from a tertiary care hospital in Mysore. They were screened for the production of biofilm, multi-drug resistance and leukotoxicity. They were also screened for icaAB and PVL luk F/S genes by PCR. Correlation between leuktoxicity and biofilm production was established by finding the leukotoxic potential of biofilm positive strains. Findings: Among 280 Staphylococcal clinical isolates, 34.6\% showed biofilm production. Out of these isolates, 25\% showed the presence of icaAB genes and 29\% showed the presence of PVL luk $F / S$ genes. Presence of $i c a A B$ gene was found to be higher in isolates obtained from implant associated infections. But the prevalence of PVL luk F/S genes was higher in chronic skin infections. $78 \%$ of the isolates displayed multi-drug resistance and methicillin resistant strains were comparitively high in device associated infections (77\%). Strong biofilm producing PVL positive isolates from chronic skin infections showed increased leucotoxicity compared to PVL negative, weak and moderate biofilm producers. Conclusion: Statistical analysis revealed that PVL in association with biofilms can promote higher leukotoxicity compared to non biofilm producers. This study foresee the essential role of biofilm production, multi-drug resistance and toxins for the increased Staphylococcal pathogenesis.
\end{abstract}

Keywords: Biofilm, Device-associated infections, Staphylococcus, Pantone-Valentine Leukocidin, ica operon

\section{Introduction}

Staphylococci are common bacterial colonizers of the skin and mucous membranes of humans and other mammals. It is an important pathogen in both community and hospital acquired infections and produces a wide spectrum of diseases, ranging from minor skin infections to fatal necrotizing pneumonia [1]. Biofilm formation is considered as major virulence factor for the increased pathogenesis in hospitalized patients [2]. Staphylococcus is known to form biofilm on indwelling devices such as urinary catheters, peripheral venous catheters, cardiac prosthetic valves, contact lens, and orthopaedic joint prosthesis and on surgical sites [2-6]. Among Staphylococci,

Manuscript received: $25^{\text {th }}$ September 2016

Reviewed: $6^{\text {th }}$ October 2016

Author Corrected: $17^{\text {th }}$ October 2016

Accepted for Publication: $30^{\text {th }}$ October 2016
Staphylococcus aureus and Staphylococcus epidermidis are frequently encountered in hospital acquired infections and they are the leading cause of biofilm associated infections [6-8]. Staphylococcal biofilms on indwelling devices are difficult to eradicate as they exhibit higher drug resistance compared to its planktonic counterparts $[9,10]$. When these devices are inserted to the patients, they are rapidly coated with host derived extracellular matrix components, plasma proteins and function as adhesin molecules for microbial attachment. In regions devoid of circulation, Staphylococci are free to grow, spread and form a resistant biofilm structure. Production of biofilm in Staphylococcus is primarily mediated by the intercellular adhesin operon (ica operon) consisting of four genes icaA, icaD, icaB and icaC [11]. ica operon is 
Research Article

frequently reported in device associated infections leading to therapeutic failure and increased hospitalization [12]. Biofilm production by Staphylococcus has also been reported in surgical site infections [13, 14], chronic skin infections such as wounds [15], abscess [16], bone infections [17], respiratory infections [18], ear infections [19] and urinary tract infections [20]. But, many reports have shown that biofilm producing Staphylococci occurs frequently on medical implants $[3,21,22]$.

Occurrence of multi-drug resistant Staphylococci are considered as a major problem in health-care set up. These isolates are implicated in increased morbidity, mortality, length of stay and expenditure of hospitalized patients 23. Studies have shown that the biofilm production in Staphylococci strongly correlates with the multi-drug resistance, higher MIC values and the presence of methicillin resistance gene cassette [24-26]. Besides, the presence of PVL toxin in Staphylococci can further increase the pathogenicity in patients [27]. The ability of this toxin to form pores in the membrane of host immune cells such as neutrophils can further progress the infection cycle [28]. PVL comprises of two secretory proteins $L u k F$-PV and $L u k S$-PV encoded by a prophage present in the bacterial genome [29]. PVL is also considered as a marker for community-acquired Methicillin Resistant Staphylococci (CA-MRSA) 30 and less frequently it has been reported in biofilm associated infections [18]. The present study was carried out to understand the synergistic effect of biofilm strength, presence of ica gene cluster, multidrug resistance and PVL toxins for the increased pathogenesis of clinical Staphylococcal strains.

\section{Materials and Methods}

Sample collection- 35 clinical Staphylococcal strains from each infection sites are collected from the clinical microbiology department of a tertiary care hospital in Mysore. A total of 280 samples were collected from this hospital. All the strains were confirmed by biochemical tests such as mannitol salt fermentation test, catalase test, DNase test and coagulase test. Based on the results obtained in Mannitol salt fermentation test and coagulase test, strains were classified into coagulase positive Staphylococci (CoPS) and coagulase negative Staphylococci (CoNS).

Quantitative analysis of biofilm production- Quantitative analysis of biofilm production in Staphylococcal isolates was performed using a modified protocol as described by Ziebuhr 12 and Stepanovic [31]. Single colony of the Staphylococcal isolate was inoculated to $25 \mathrm{ml}$ trypticase soy broth (TSB) and incubated at 37oC for 8-10 hours until 0.5 OD is obtained. After incubation, cells were centrifuged and washed thrice with phosphate buffer saline and diluted to 1000 times in TSB to get an OD of 0.1. Cell suspension of $200 \mu 1$ was inoculated to 96 wells flat bottom microtitre plate (Tarsons) in triplicates and incubated at 37oC for 48 hours. S. epidermidis (RP62A) ATCC 35984 was used as a positive control and 3 wells with TSB alone were used as negative control. After incubation, plates were washed thrice with 0.15 M sterile PBS and stained with $1 \%$ crystal violet (HiMedia Labs Mumbai, India) for 5 minutes at room temperature. Stained microtitre plates are again washed thrice with sterile distilled water and dried in hot air oven at $45 \mathrm{oC}$. The bound dye was resolubilized by adding $160 \mu \mathrm{l}$ of $33 \%$ (v/v) glacial acetic acid to each well and kept for 30 minutes at room temperature. The resolubilized dye was transferred to a new microtitre plate and OD was measured at $570 \mathrm{~nm}$ in a spectrophotometer (Thermo-Fischer Scientific). Based on the obtained OD values, quantification of biofilm strength was performed using a formula as described by Stepanovic 30. At first the cut off OD (ODc) was calculated using the formula

\section{ODc $=$ Average OD of negative control $+3 \times$ SD of negative control.}

The ODc was compared with the OD of samples (ODs) and the strength of biofilm production observed in each isolate was assessed using the following formula

If ODs $\leq$ ODc then Non-adherent

If ODc $<$ ODs $\leq 2 \times$ ODc then Weakly adherent

If $2 \times$ ODc < ODs $\leq 4 \times$ ODc then Moderately adherent

If $4 \times$ ODc < ODs < ODc then Strongly adherent

Identification of multi-drug resistance in biofilm positive isolates- Susceptibilities to antibiotics such as cefoxitin, ciprofloxacin, clindamycin, erythromycin, gentamicin, rifampicin, tetracycline, cotrimoxazole and linezolid are determined by the Kirby-Bauer agar disc diffusion method [32]. Interpretation criteria for susceptibility tests are carried out as per the CLSI guidelines [33]. Isolates which showed resistance to more than three classes of antibiotics and cefoxitin are considered as multi-drug resistant and methicillin resistant isolates respectively. 


\section{Detection of intercellular adhesin (ica) gene cluster and PVL gene by PCR}

DNA isolation by heat lysis method- DNA from all the isolates is obtained by heat lysis method. Single colony of each isolate was transferred to $100 \mu 1$ of sterile distilled water taken in $500 \mu 1$ eppendorf tube. Tubes were placed in dry bath at $100 \mathrm{oC}$ for 10 minutes. Later, the tubes were spinned briefly for 1 minute at 2000 RPM and the lysate obtained was used for PCR.

PCR conditions- All the reagents for PCR were procured from HiMedia Labs Mumbai. PCR for all the isolates was carried out in a $25 \mu 1$ reaction containing $5 \mu 1$ of cell lysate and $20 \mu 1$ of master mix consisting of PCR grade water, 1.5 $\mathrm{mM} \mathrm{MgCl2,10X} \mathrm{PCR} \mathrm{buffer,} 4$ pico-moles of respective forward and reverse primers, $0.4 \mathrm{mM} \mathrm{dNTP} \mathrm{mix} \mathrm{and} 0.04 \mathrm{U}$ Taq polymerase. For the detection of ica gene cluster the primers for icaAB genes designed by Frebourg 34 was used. PCR programme was set with an initial denaturation at $94^{\circ} \mathrm{C}$ for 5 minutes followed by 35 cycles of 30 seconds of denaturation at $94^{\circ} \mathrm{C}, 30$ seconds of annealing at $55^{\circ} \mathrm{C}$ and 60 seconds of extension at $72^{\circ} \mathrm{C}$. Final extension at $72^{\circ} \mathrm{C}$ for 10 minutes was set as the last step of PCR programme. PCR was carried out in Eppendorf Master Cycler PCR machine Germany. To detect the presence of PVL-lukF/S genes the primers designed by Lina was used [35]. The programme was set similar to $i c a A B$ detection but the annealing temperature was $52^{\circ} \mathrm{C}$ for 45 seconds. The sequence of primers used for molecular detection of $i c a A B$ and PVL-lukF/S genes are mentioned in Table 1. $10 \mu 1$ of amplified PCR products along with $1 \mathrm{~KB}$ DNA marker were analyzed on $2 \%$ agarose gel electrophoresis and captured in a gel documentation system.

Table-1: Sequence of primers used for the detection of $i c a A B$ and PVL $l u k F / S$ genes

\begin{tabular}{|c|c|c|}
\hline Name of the gene & Primer sequence & Reference \\
\hline icaAB & $\begin{array}{c}\text { icaAB - F } \\
\text { 5' - TCTTGCAGCCGATGTCATTA - 3' } \\
\text { icaAB - R } \\
\text { 5' - ATGCTTGCGAGCGCTAAGTT - 3' }\end{array}$ & {$[34]$} \\
\hline PVL lukF/S & $\begin{array}{c}\text { Luk PV-F } \\
\text { 5-ATCATTAGGTAAAATGTCTGGACATGATCCA-3 } \\
\text { Luk PV-R } \\
\text { 5-GCATCAAGTGTATTGGATAGCAAAAGC-3 }\end{array}$ & [35] \\
\hline
\end{tabular}

Leukotoxicity assay-The leukotoxic potential of PVL positive isolates using MTT (3-(4,5-dimethylthiazol-2-yl)-2,5diphenyltetrazolium) was performed by a modified protocol as described by Chung [36] and Padmaja [37].

Preparation of leukotoxin-Single colony of PVL positive isolates were initially grown on $20 \mathrm{ml}$ of $\mathrm{TSB}$ at $37^{\circ} \mathrm{C}$ until it reached the late exponential phase. Further, cells were centrifuged at 8000 rpm and resuspended in RPMI 1640 (SigmaAldrich) medium supplemented with 5\% fetal bovine serum (Gibco Laboratories). This suspension was incubated for 75 minutes in a shaker incubator at $37^{\circ} \mathrm{C}$. Centrifugation was repeated at $8000 \mathrm{rpm}$ to remove the cells. The supernatant obtained was filtered using a $0.45 \mu \mathrm{m}$ and $0.22 \mu \mathrm{m}$ membrane filters. 2 folds dilution of this filtrate was used for the leukotoxicity assay.

Preparation of neutrophils- Neutrophils separated from whole blood of a healthy individual were kindly provided by the Department of Pathology, JSS Medical College, Mysore and used for the assay. Neutrophils were resuspended in PBS supplemented with $0.5 \mathrm{mM}$ glucose and $1 \%$ fetal bovine serum. This suspension was diluted to get $12.5 \times 10^{4}$ cells per well which was equal to $0.5 \mathrm{OD}$.

MTT assay- $100 \mu 1$ of neutrophils were transferred to flat bottom sterile microtitre wells in triplicates and 2 folds dilution of $50 \mu \mathrm{l}$ PVL suspension was added. Plates were incubated at $37^{\circ} \mathrm{C}$ for 1 hour. PVL untreated wells with $200 \mu \mathrm{l}$ of neutrophils suspension alone was used as the control for the assay. After incubation $20 \mu \mathrm{lof} 5 \mathrm{mg} / \mathrm{ml}$ (w/v) of MTT was added to PVL treated and untreated wells and incubated for 4 hours at $37^{\circ} \mathrm{C}$. Neutrophils which were killed after PVL treatment showed diminished electron transport system and could not reduce the tetrazolium salt to a water soluble purple formazan crystal. But, viable neutrophils formed this crystal by reduction. The formazan crystal was resolubilized by adding $200 \mu \mathrm{l}$ of DMSO to all the treated and untreated wells and incubated for 15 minutes at room temperature. OD was measured at $570 \mathrm{~nm}$ in a visible spectrophotometer. 
Determination of toxic potential of PVL positive isolates- The percent leukotoxicity was calculated using the formula

Percent leukotoxicity $=1$ - $($ OD of cell treated with PVL/ OD of untreated cells $) \times 100-$ A 2 folds dilution of leukotoxin preparation which can kill $50 \%$ of human neutrophils under the above mentioned conditions gives the toxic unit of strains. This was calculated by linear regression of the percent cytotoxicity and the corresponding 2 folds dilution of the prepared cytotoxin as described by Chung [35]. Isolates which showed higher toxic units are considered as toxic strains.

\section{Results}

Isolation and confirmation of Staphylococci- 35 Staphylococcal strains from each infected site or medical implant were collected from a tertiary care hospital in Mysore to get a total of 280 samples. DNase test, Catalase test and mannitol salt fermentation test further confirmed that the isolates belong to Staphylococci. Based on the coagulase test and mannitol salt fermentation test $62.5 \%$ of the isolates were found to be $S$. aureus and remaining $37.5 \%$ were CoNS. The prevalence of $S$. aureus was comparatively more in chronic skin infections and abscess. Whereas CoNS were found to be higher in device associated infections and bone infections. Table 2 shows the prevalence of $S$. aureus and CoNS isolated from the infected sites and medical implants.

Table-2: Prevalence of $S$. aureus and CoNS isolated from infected sites.

\begin{tabular}{|c|c|c|}
\hline Isolation sites & Number of S. aureus & Number of CoNS \\
\hline Post-operative infections & 21 & 6 \\
\hline Chronic skin infections & 29 & 4 \\
\hline Abscess & 31 & 29 \\
\hline Implant associated infections & 6 & 17 \\
\hline Bone infections & 18 & 3 \\
\hline Otitis media & 32 & 8 \\
\hline Respiratory infections & 27 & 24 \\
\hline Urinary tract infections & 11 & $\mathbf{1 0 5}(\mathbf{3 7 . 5 \%})$ \\
\hline Total & $\mathbf{1 7 5}(\mathbf{6 2 . 5 \% )}$ & 6 \\
\hline
\end{tabular}

Table-3: Number of biofilm positive isolates and their characteristics.

\begin{tabular}{|c|c|c|c|c|c|c|}
\hline Site of isolation & $\begin{array}{c}\text { Total no. of } \\
\text { biofilm } \\
\text { positive } \\
\text { isolates }\end{array}$ & $\begin{array}{c}\text { No. of } \\
\text { strong } \\
\text { biofilm } \\
\text { producers }\end{array}$ & \begin{tabular}{|c} 
No. of \\
moderate \\
biofilm \\
producers
\end{tabular} & $\begin{array}{c}\text { No. of weak } \\
\text { biofilm } \\
\text { producers }\end{array}$ & $\begin{array}{c}\text { No. of } i c a A B \\
\text { positive } \\
\text { isolates }\end{array}$ & $\begin{array}{c}\text { No. of PVL luk } \\
F / S \text { positive } \\
\text { isolates }\end{array}$ \\
\hline $\begin{array}{c}\text { Post-operative } \\
\text { infections }\end{array}$ & 7 & 3 & 2 & 2 & 3 & 2 \\
\hline $\begin{array}{c}\text { Chronic skin } \\
\text { infections }\end{array}$ & 33 & 23 & 6 & 4 & 6 & 8 \\
\hline Abscess & 16 & 5 & 2 & 9 & 3 & 3 \\
\hline $\begin{array}{c}\text { Implant } \\
\text { associated } \\
\text { infections }\end{array}$ & 30 & 7 & 4 & 19 & 7 & 4 \\
\hline Bone infections & 6 & 6 & 0 & 0 & 2 & 2 \\
\hline Otitis media & 2 & 0 & 1 & 1 & 0 & 1 \\
\hline $\begin{array}{c}\text { Respiratory } \\
\text { infections }\end{array}$ & 4 & 4 & 0 & 0 & 1 & 2 \\
\hline $\begin{array}{c}\text { Urinary tract } \\
\text { infections }\end{array}$ & 2 & 1 & 0 & 1 & 2 & 2 \\
\hline Total & 97 & 49 & 15 & 36 & 24 & 28 \\
\hline
\end{tabular}


Quantitative analysis of biofilm production- By using the formula as described above, isolates were classified into non-adherent, weakly adherent, moderately adherent and strongly adherent. Out of 280 samples, 97 isolates (34.6\%) showed biofilm production. It was prominent in isolates obtained from chronic skin infections and device associated infections. However, strong biofilm producers were comparatively high in isolates obtained from chronic skin infections and bone infections. Site of infection, number of biofilm positive isolates and their respective strength are shown in Table 3.

Antibiogram of biofilm positive isolates- By using Kirby Bauer agar disc diffusion method, 97 biofilm positive isolates were checked for antimicrobial susceptibility. 76 isolates were found to be multi-drug resistant and the percentage was higher in isolates obtained from device associated infections followed by chronic skin infections. Methicillin resistant isolates were found to be more in device associated infections when compared to other isolates. Interestingly, 4 isolates from chronic skin infections also showed resistance to Linezolid. Table 4 shows the number of isolates showing resistance to the screened antibiotics.

Table-4: Number of biofilm positive isolates and their resistance to screened antibiotics.

\begin{tabular}{|c|c|c|c|c|c|c|c|c|c|c|}
\hline \multirow[t]{2}{*}{ Site of isolation } & \multirow{2}{*}{$\begin{array}{l}\text { No. of } \\
\text { biofilm } \\
\text { positive } \\
\text { isolates }\end{array}$} & \multicolumn{9}{|c|}{ Number of resistant isolates } \\
\hline & & 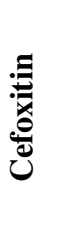 & 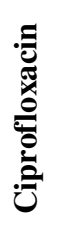 & 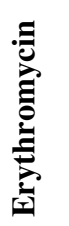 & 芯 & 氕 & 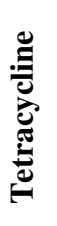 & : & 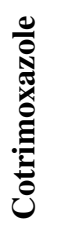 & 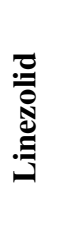 \\
\hline Post-operative infections & 7 & 4 & 2 & 5 & 2 & 3 & 1 & 1 & 1 & 0 \\
\hline Chronic skin infections & 33 & 23 & 25 & 28 & 12 & 27 & 8 & 3 & 20 & 4 \\
\hline Abscess & 16 & 10 & 7 & 14 & 8 & 14 & 5 & 3 & 13 & 0 \\
\hline $\begin{array}{c}\text { Implant associated } \\
\text { infections }\end{array}$ & 30 & 27 & 20 & 24 & 6 & 21 & 7 & 5 & 23 & 0 \\
\hline Bone infections & 6 & 3 & 1 & 4 & 0 & 3 & 0 & 0 & 4 & 0 \\
\hline Otitis media & 2 & 1 & 0 & 2 & 0 & 2 & 0 & 0 & 1 & 0 \\
\hline Respiratory infections & 4 & 3 & 0 & 1 & 0 & 2 & 1 & 0 & 1 & 0 \\
\hline Urinary tract infections & 2 & 1 & 0 & 0 & 1 & 1 & 1 & 0 & 1 & 0 \\
\hline
\end{tabular}

Molecular screening of $\boldsymbol{i c a A B}$ and PVL $\boldsymbol{l u k F / S}$ genes- Out of 97 biofilm positive isolates, 24 showed the presence of $i c a A B$ genes. These genes were found to be higher in device associated infections followed by chronic skin infections. A total of $28 \mathrm{~S}$. aureus isolates out of 97 biofilm positive strains showed the presence of PVL lukF/S genes. The prevalence was higher in isolates obtained from chronic skin infections followed by abscess. Isolated sites and the prevalence of $i c a A B$ and PVL $l u k F / S$ genes are shown in Table 3. Figure 2 and 3 shows the agarose gel with amplified PCR products of $i c a A B$ and PVL $l u k F / S$ genes.

Figure-1: Molecular screening of $i c a A B$ genes

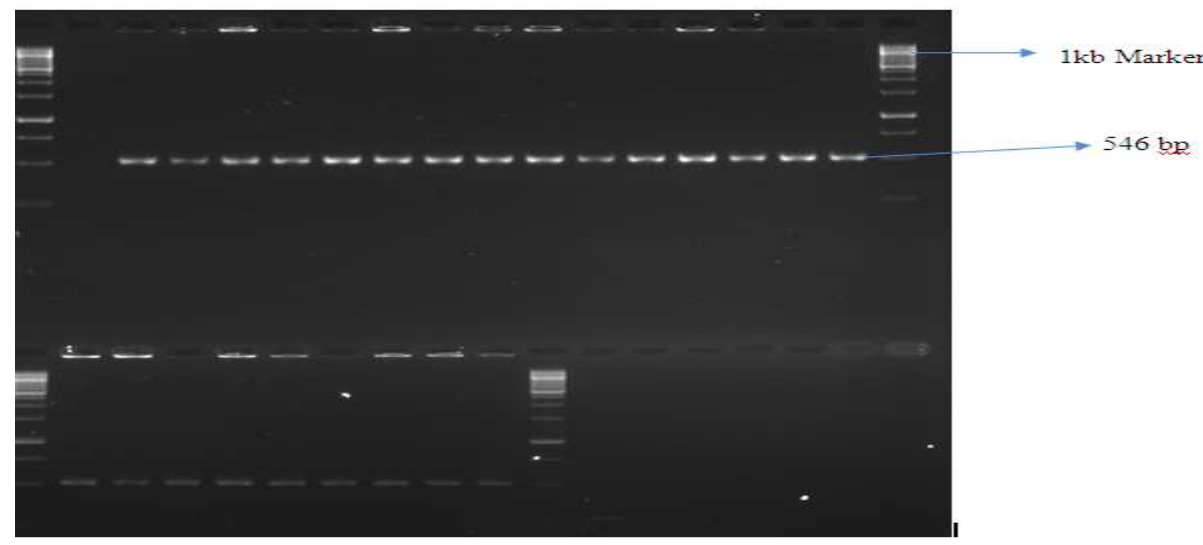


Research Article

Figure-2: Molecular screening of PVL $l_{l}^{\prime} k F / S$ genes

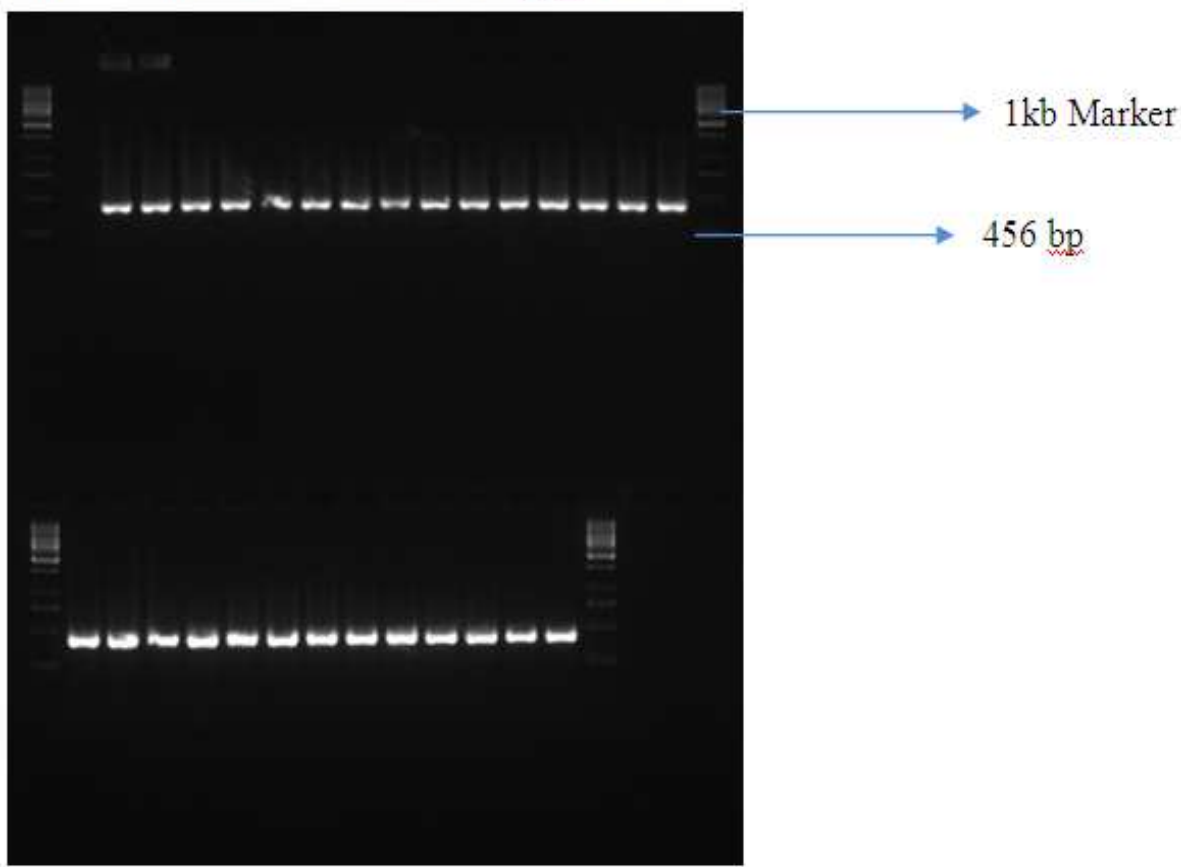

Leukotoxic potential of PVL positive isolates- Isolates which showed 50\% leucotoxicity in MTT assay are considered as toxigenic strains. Percent leucotoxicity, dilution factor and toxic units of these strains are shown in Table 5. Biofilm producing PVL positive strains isolated from chronic skin infections were comparatively high with an average toxic unit of 477.71. Out of 28 PVL positive isolates 13 showed higher toxic units, icaAB genes, produced strong biofilms and displayed multi-drug resistance. Table 6 shows the characteristic features and clinical symptoms associated with these isolates.

Table-5: Leukotoxic potential of biofilm positive isolates.

\begin{tabular}{|c|c|c|c|}
\hline Site of isolation & $\begin{array}{c}\text { No of PVL positive and } \\
\text { biofilm producing strains }\end{array}$ & Mean dilution factor & Mean leukotoxic units \\
\hline Post operative infections & 2 & 24.9 & 29.85 \\
\hline Chronic skin infections & 8 & 28.9 & 377.71 \\
\hline Abscess & 3 & 28.3 & 315.17 \\
\hline $\begin{array}{c}\text { Implant associated } \\
\text { infections }\end{array}$ & 4 & 24.8 & 27.85 \\
\hline Bone infections & 2 & 25.8 & 55.71 \\
\hline Otitis media & 1 & 23.9 & 14.92 \\
\hline Respiratory infections & 2 & 24.6 & 24.25 \\
\hline Urinary tract infections & 2 & & \\
\hline
\end{tabular}

Statistical analysis-To understand the synergistic effect of biofilm production, PVL toxin and multidrug resistance on Staphylococcal pathogenesis, we carried out Fischer's exact test using the SPSS software version 14.0. Two-tailed pvalue was found to be lesser than 0.05 and thus our results are statistically significant.

Our findings indicate that there is correlation between strong biofilm production (ica+), presence of PVL $(l u k F / S+)$ and high leukotoxic potential of the strains. 
Research Article

Table-6: Characteristics of 13 Strong biofilm producing, PVL +, icaAB + and Multidrug resistant strains

\begin{tabular}{|c|c|c|c|}
\hline Sample no. & Source of isolation & Clinical symptoms & Leukotoxic potential in toxic units \\
\hline S14 & Cellulitis & $\begin{array}{l}\text { Severe inflammation with } \\
\text { pain }\end{array}$ & 315.17 \\
\hline S18 & Supparative lesion & Fever with pain & 362.03 \\
\hline $\mathbf{S 4 3}$ & $\begin{array}{l}\text { Peripheral venous } \\
\text { catheter }\end{array}$ & Early onset Septicaemia & 294.06 \\
\hline S47 & $\begin{array}{c}\text { Peripheral venous } \\
\text { catheter }\end{array}$ & Late onset septicaemia & 386.24 \\
\hline $\mathbf{S 5 3}$ & Urinary catheter & Burning micturition, fever & 274.37 \\
\hline S55 & Joint prosthesis & $\begin{array}{l}\text { Fever, inflammation and } \\
\text { pain in the implanted site }\end{array}$ & 194.01 \\
\hline S56 & $\begin{array}{l}\text { Post-operative } \\
\text { infection }\end{array}$ & $\begin{array}{c}\text { Fever, pain with } \\
\text { septicaemia }\end{array}$ & 315.17 \\
\hline S63 & Furuncle & $\begin{array}{l}\text { Severe pain in the site of } \\
\text { infection, fever and fatigue }\end{array}$ & 238.85 \\
\hline S66 & Carbuncle & $\begin{array}{l}\text { Severe pain in the site of } \\
\text { infection and fever }\end{array}$ & 256 \\
\hline S75 & Impetigo & $\begin{array}{c}\text { Itchy skin, swollen lymph } \\
\text { nodes }\end{array}$ & 388.02 \\
\hline S79 & Otitis media & $\begin{array}{c}\text { Severe pain in the middle } \\
\text { ear, increased nasal } \\
\text { discharge }\end{array}$ & 227.54 \\
\hline S86 & $\begin{array}{l}\text { Post plastic surgery } \\
\text { infection }\end{array}$ & $\begin{array}{c}\text { Severe pain and } \\
\text { inflammation in the } \\
\text { operated site }\end{array}$ & 119.42 \\
\hline S93 & Bronchiectasis & $\begin{array}{l}\text { Dilated bronchi with } \\
\text { inflammation and difficult } \\
\text { to breath }\end{array}$ & 256 \\
\hline
\end{tabular}

\section{Discussion}

Biofilm formation is considered as a major problem in hospitals. Infection caused by biofilm forming Staphylococci can prolong the treatment strategies of patients and length of their stay in hospitals. Emergence of multi-drug resistant Staphylococci can further complicate the infection leading to increased morbidity and mortality of patients. Recent prevalence report from a two different tertiary care hospital in Mysore has shown that methicillin resistant CoNS are higher in neonates [38] and nearly $79 \%$ of health care personnel carry methicillin resistant Staphylococci [39]. The occurrence of linezolid resistant isolates is also reported from Mysore [40]. A study from Istanbul, Turkey showed higher biofilm production and PVL production by staphylococcal strains isolated from cystic fibrosis patients [18]. None of these findings have explained the importance of biofilm production, multidrug resistance and PVL genes in the increased pathogenesis of Staphylococci. Earlier studies have shown that Staphylococcal isolates obtained from device-associated infections often form strong biofilms [2]. But our results shows that biofilm formation can be observed even in surgical site infections, otitis media, bone infections, abscess, respiratory infections and chronic skin infections. Out of 280 samples isolated from different infection sites, 97 showed biofilm production. The percentage of biofilm producing strains was higher in chronic skin infections $(97 \%)$ when compared to implant associated infections (86\%). Our results supports the earlier findings wherein biofilm production need not be always associated with device associated infections, but can be observed even in non-device associated infections [13-20]. The antibiogram of biofilm positive isolates revealed that $78 \%$ of the biofilm positive isolates were multi-drug resistant and majority of these isolates were obtained from device associated infections. When we assessed the prevalence of methicillin resistance, it was higher in device associated infections. Our findings confirmed that multi-drug resistant and methicillin resistant strains have higher tendency to develop biofilms on medical 
Research Article

devices [25]. ica operon promotes strong biofilm production in Staphylococci. Out of 97 isolates only 24 showed the presence of $i c a A B$ genes. This finding opines that, biofilm production need not be always ica dependent. However, the increased strength of biofilm production is mediated by the presence of ica operon. PVL is considered as a marker for the severity of Staphylococcal infections [27] as well as a marker for CA-MRSA infections [30]. To correlate the significance of PVL production, biofilm production and multi-drug resistance, all the biofilm positive isolates were initially screened for the presence of PVL $l u k F / S$ genes. Our data revealed that $28.86 \%$ of biofilm positive isolates were PVL positive and displayed a varied leukotoxic potential in MTT assay. High leucotoxicity was observed in the isolates obtained from chronic skin infections followed by implant associated infections. These data supports the earlier findings that PVL is very active in chronic skin infections and can prolong the treatment with high leucotoxicity [35]. To understand the significance of biofilm production, multidrug resistance and high leucotoxicity, statistical analysis was carried out using Fischer's exact test. It revealed a strong correlation between PVL production, biofilm and multi-drug resistance. Our overall results suggest that identifying the drug resistance pattern, strength of biofilm production and leukotoxic potential of biofilm forming clinical strains is crucial to give an effective treatment for the patients suffering from biofilm associated infections in hospitals.

\section{Conclusion}

Our study represents a three-way diagnostic model for the detection of virulent biofilm forming staphylococcal clinical isolates. We were able to identify strong correlation in PVL toxin production and biofilm formation in $S$. aureus strains. CoNS strains displayed strong biofilm phenotype and they were also identified as multidrug resistant strains. Most of the studies stressed on identifying biofilms in device-associated strains. But here we mainly focused on strains obtained from non-device associated infections. Interestingly, these strains also displayed biofilm production and showed the presence of icaAB genes. Thus our overall study represents a unique tripartite diagnostic model for understanding the virulence factors in clinical staphylococcal strains.

Acknowledgement: Authors thank the Indian Council of Medical Research, Government of India for the senior research fellowship (ICMR award letter No. 80/763/2012-ECD-I dated 02.04.2013).
Funding: Nil, Conflict of interest: None initiated, Permission from IRB: Yes

\section{References}

1. Gillet Y, Vanhems P, Lina G, Bes M, Vandenesch F, Floret D, Etienne J. Factors predicting mortality in necrotizing community-acquired pneumonia caused by Staphylococcus aureus containing Panton-Valentine leukocidin. Clin Infect Dis. 2007 Aug 1;45(3):315-21. Epub 2007 Jun 15.

2. Von Eiff C, Jansen B, Kohnen W, Becker K. Infections associated with medical devices: pathogenesis, management and prophylaxis. Drugs. 2005; 65 (2):179-214.

3. McCann MT, Gilmore BF, Gorman SP. Staphylococcus epidermidis device-related infections: pathogenesis and clinical management. Journal of Pharmacy and Pharmacology. 2008; 60(12):1551-71.

4. Costerton JW, Montanaro L, Arciola CR. Biofilm in implant infections: its production and regulation. Int $\mathbf{J}$ Artif Organs. 2005 Nov;28(11):1062-8.

5. Donlan RM. Biofilms and device-associated infections. Emerg Infect Dis.2001Mar-Apr;7(2):277-81.

6. Hooper S, Percival S, Cochrane C, Williams D. Biofilms and Implication in Medical Devices in Humans and Animals. In: Percival S, Knottenbelt D, Cochrane C, editors. Biofilms and Veterinary Medicine. Springer Series on Biofilms. 6: Springer Berlin Heidelberg; 2011. p. 191-203.

7. Murugan K, Usha M, Malathi P, Al-Sohaibani AS, Chandrasekaran M. Biofilm forming multi drug resistant Staphylococcus spp. among patients with conjunctivitis. Pol J Microbiol. 2010;59(4):233-9.

8. O'Grady NP, Alexander M, Burns LA, Dellinger EP, Garland J, Heard SO, et al. Guidelines for the prevention of intravascular catheter-related infections. American Journal of Infection Control. 2011;39(4): S1-S34.

9. Gilbert P, Das J, Foley I. Biofilm susceptibility to antimicrobials. Adv Dent Res. 1997 Apr;11(1):160-7.

10. Ceri H, Olson ME, Stremick C, Read RR, Morck D, Buret A. The Calgary Biofilm Device: new technology for rapid determination of antibiotic susceptibilities of bacterial biofilms. J Clin Microbiol. 1999 Jun;37 (6):1771-6. 
11. Heilmann C, Schweitzer O, Gerke C, Vanittanakom N, Mack D, Götz F. Molecular basis of intercellular adhesion in the biofilm-forming Staphylococcus epidermidis. Molecular Microbiology. 1996; 20 (5): 1083-91.

12. Ziebuhr W, Heilmann C, Götz F, Meyer P, Wilms K, Straube E, Hacker J. Detection of the intercellular adhesion gene cluster (ica) and phase variation in Staphylococcus epidermidis blood culture strains and mucosal isolates. Infect Immun. 1997 Mar;65(3):890-6.

13. Kathju S, Nistico L, Hall-Stoodley L, Post JC, Ehrlich GD, Stoodley P. Chronic Surgical Site Infection Due to Suture-Associated Polymicrobial Biofilm. Surgical Infections. 2009;10(5):457-61.

14. Pulcrano G, Vollaro A, Rossano F, Catania MR. Molecular and Phenotypic Characterization of Methicillin-Resistant Staphylococcus aureus from Surgical Site Infections. Surgical Infections. 2013;14 (2):196-202.

15. Metcalf DG, Bowler PG. Biofilm delays wound healing: A review of the evidence. Burns Trauma. 2013 Jun 18;1(1):5-12. doi: 10.4103/2321-3868.113329. eCollection 2013.

16. Cheng AG, DeDent AC, Schneewind O, Missiakas D. A play in four acts: Staphylococcus aureus abscess formation. Trends Microbiol. 2011 May;19(5):225-32. doi: 10.1016/j.tim.2011.01.007. Epub 2011 Feb 25.

17. Brady RA, Leid JG, Calhoun JH, Costerton JW, Shirtliff ME. Osteomyelitis and the role of biofilms in chronic infection. FEMS Immunol Med Microbiol. 2008 Jan;52(1):13-22. Epub 2007 Dec 11.

18. Aktas NC, Erturan Z, Karatuna O, Yagci AK. Panton-Valentine leukocidin and biofilm production of Staphylococcus aureus isolated from respiratory tract. Journal of Infection in Developing Countries. 2013;7(11):888-91.

19. Paluch-Oleś J, Magryś A, Kozioł-Montewka M, Niedzielski A, Niedźwiadek J, Niedzielska G, Kotowski M. The phenotypic and genetic biofilm formation characteristics of coagulase-negative staphylococci isolates in children with otitis media. Int $\mathbf{J}$ Pediatr Otorhinolaryngol. 2011 Jan;75(1):126-30. doi: 10 . 1016/j. ijporl. 2010.10.025. Epub 2010 Nov 18.

20. Ando E, Monden K, Mitsuhata R, Kariyama R, Kumon $\mathrm{H}$. Biofilm formation among methicillinresistant Staphylococcus aureus isolates from patients with urinary tract infection. Acta Medica Okayama. 2004; 58(4):207-14.

21. Arciola CR, Alvi FI, An YH, Campoccia D, Montanaro L. Implant infection and infection resistant materials: A mini review. International Journal of Artificial Organs. 2005; 28(11):1119-25.

22. Singhai M, Malik A, Shahid M, Malik MA, Goyal R. A study on device-related infections with special reference to biofilm production and antibiotic resistance. J Glob Infect Dis. 2012;4(4):193-8.

23. Cosgrove SE, Qi YL, Kaye KS, Harbarth S, Karchmer AW, Carmeli Y. The impact of methicillinresistance in Staphylococcus aureus bacteremia on patient outcomes: Mortality, length of stay, and hospital charges. Infection Control and Hospital Epidemiology. 2005; 26(2):166-74.

24. Agarwal A, Jain A. Association between drug resistance \& production of biofilm in staphylococci. Indian Journal of Medical Research. 2012;135(4): 562-4.

25. Kwon AS, Park GC, Ryu SY, Lim DH, Lim DY, Choi CH, Park Y, Lim Y. Higher biofilm formation in multidrug-resistant clinical isolates of Staphylococcus aureus. Int J Antimicrob Agents. 2008 Jul;32(1):68-72. doi: 10.1016/j. ijantimicag. 2008. 02. 009. Epub 2008 Jun 5.

26. Pozzi C, Waters EM, Rudkin JK, Schaeffer CR, Lohan AJ, Tong P, et al. Methicillin Resistance Alters the Biofilm Phenotype and Attenuates Virulence in Staphylococcus aureus Device-Associated Infections. Plos Pathogens. 2012;8(4).

27. Etienne J. Panton-Valentine leukocidin: a marker of severity for Staphylococcus aureus infection? Clin Infect Dis. 2005 Sep 1;41(5):591-3. Epub 2005 Jul 29.

28. Szmigielski S, Prevost G, Monteil H, Colin DA, Jeljaszewicz J. Leukocidal toxins of staphylococci. Zentralblatt Fur Bakteriologie-International Journal of Medical Microbiology Virology Parasitology and Infectious Diseases. 1999; 289(2):185-201.

29. Prevost G, Cribier B, Couppie P, Petiau P, Supersac G, Finckbarbancon V, et al. Panton-Valentine Leucocidin and gamma-hemolysin from Staphylococcus aureus ATCC-49775 are encoded by distinct genetic-loci and have different biological activities. Infection and Immunity. 1995; 63 (10) : 4121-9. 
Research Article

30. Lo WT, Wang CC. Panton-Valentine Leukocidin in the Pathogenesis of Community-associated Methicillinresistant Staphylococcus aureus Infection. Pediatrics and Neonatology. 2011;52(2):59-65.

31. Stepanovic S, Vukovic D, Dakic I, Savic B, SvabicVlahovic M. A modified microtiter-plate test for quantification of staphylococcal biofilm formation. Journal of Microbiological Methods. 2000;40(2):175-9.

32. Bauer AW, Kirby WM, Sherris JC, Turck M. Antibiotic susceptibility testing by a standardized single disk method. Am J Clin Pathol. 1966 Apr;45(4):493-6.

33.Clinical Laboratory Standards Institute. Performance standards for antimicrobial susceptibility testing; Twenty Second Informational Supplement. 2012;32(3). Document M100-S22, Wayne, PA.

34. Frebourg NB, Lefebvre S, Baert S, Lemeland JF. PCR-Based assay for discrimination between invasive and contaminating Staphylococcus epidermidis strains. J Clin Microbiol. 2000 Feb;38(2):877-80.

35. Lina G, Piémont Y, Godail-Gamot F, Bes M, Peter MO, Gauduchon V, Vandenesch F, Etienne J. Involvement of Panton-Valentine leukocidin-producing Staphylococcus aureus in primary skin infections and pneumonia. Clin Infect Dis. 1999 Nov;29(5):1128-32.
36. Chung WB, Bäckström LR, McDonald J, Collins MT. The (3- (4, 5- dimethylthiazol- 2- yl)- 2, 5diphenyltetrazolium) colorimetric assay for the quantitation of Actinobacillus pleuropneumoniae cytotoxin. Can J Vet Res. 1993 Jul;57(3):159-65.

37. Padmaja RJ, Halami PM. Molecular Characterization and Toxicity Confirmation of Luk M/F'-PV Producing Staphylococcus aureus Isolated from Bovine Mastitis Samples in Mysore, India. Indian Journal of Microbiology. 2013;53(3):276-82.

38. Deepa S, Kumari A, Venkatesha D. Increasing trends of methicillin resistant coagulase negative Staphylococcus in neonatal septicaemia - a study in a tertiary care hospital, Mysore, South India. Online Journal of Health and Allied Sciences 2010, 9(4):1-3.

39. Annu T, Sumana M, Umamaheshwari S. Screening health care personnel for detection of methicillin resistant of Staphylococcus aureus carrier state at a tertiary care hospital in Mysore. International Journal of Pharmaceutical Science Invention 2013;2(7):12-15.

40. Lyra PR, Anuradha K, Shilpa A, Venkatesha D. Linezolid resistance in isolates of methicillin resistant Staphylococci from blood cultures. International Journal of Pharma and Biosciences 2013; 4 (4): $1085-1090$

\section{How to cite this article?}

Pradeep Halebeedu Prakash, Gopal S. Prevalence and leukotoxic profile of biofilm forming Staphylococcal strains isolated from a tertiary care hospital in Mysore.Trop J Path Micro 2016;2(3):110-119.doi: 10.17511/jopm.2016.i03.06 